METALLURGY AND FOUNDRY ENGINEERING - Vol. 37, 2011, No. 1

Katarzyna Major-Gabryś*, Stanisław M. Dobosz**

\title{
THE INFLUENCE OF THE GLASSEX ADDITIVE ON TECHNOLOGICAL AND KNOCK-OUT PROPERTIES OF THE MOULDING SANDS WITH HYDRATED SODIUM SILICATE AND NEW ESTER HARDENERS
}

\section{INTRODUCTION}

Requirements for high castings quality cause scientific investigations leading to obtain moulding and core sands having not only good technological properties, but also being environmental friendly. In the Department of Moulding Materials on Faculty of Foundry Engineering AGH (University of Science and Technology) there were investigations taken to elaborate new binding systems based on ecological inorganic binders. The biggest group are the moulding sands with hydrated sodium silicate called moulding sands with water glass. Unfortunately inorganic binder character causes mouldings' low knock-out properties and their low ability to mechanical reclamation. Authors' researches on the first stage considered elaborating and patenting moulding sands with new Glassex additive having improved knock-out properties. In the previous publications, authors [1-8] showed that inserting a new additive Glassex to moulding sands with water glass carried out in ester technology improved their knock-out properties defined (measured) according to technological test [1-4] and according to retained strength examination [1, 4-5]. Lowering the retained strength of moulding sand in measured range of temperature and moving the second maximum on the curve into direction of higher temperatures (very rarely existing in foundry moulding sands) were noticed.

The second stage of authors researches were investigations concerning the improving of regenerated moulding sand quality. The point of researches was to - supposing that there

* Ph.D., **Prof. Ph.D., D.Sc., Faculty of Foundry Engineering, AGH University of Science and Technology, Kraków, Poland; e-mail: Katarzyna.Major-Gabrys@agh.edu.pl 
is always some binding material left on grains after the mechanical reclamation - make the traces (rests) left on grains after the reclamation not to decrease regenerated moulding sands quality, as it happens in floster technology. The own researches $[6,7]$ and the analysis of scientific paper [8-10] showed that the sodium acetate that is obtained in the reaction of water glass with acetic acid ester accumulates in the process of mechanical reclamation leading to the fall of moulding sand's bending properties and its wear resistance. As a result of researches two alternative ester hardeners were elaborated: based on carbonate acid ester - propylene carbonate having trade name Ixional SD, and based on carbonate acid ester butylene carbonate having trade name Jefsol BC. In the reaction of water glass with carbonate acid ester sodium carbonate is obtained which rests on grains after reclamation are not harmful. The own researches of moulding sands with water glass and new ester hardeners were showed in many publications [6, 7, 11-14].

The article presents the results of authors' own investigations of the moulding sand composition that combines the new hardener and the new additive properties.

\section{EXPERIMENTAL RESULTS}

In the article there are presented researches showing the Glassex additive influence on bending strength, wear resistance, knock-out properties and thermal expansion of moulding sand with water glass and alternative to flodur hardeners - the new ester hardeners: Ixional $\mathrm{SD}$ and Jefsol BC. Moulding sands with following composition were taken into elaboration:

$\begin{array}{ll}\text { Quartz sand } & 100 \text { parts by weight } \\ \text { Water glass 145 } & 3 \text { parts by weight } \\ \text { Ixional SD or Jefsol BC } & 0.3 \text { part by weight } \\ \text { Glassex } & 0.5-1.0 \text { part by weight }\end{array}$

\subsection{The investigations of Glassex additive influence on technological properties of moulding sand with water glass}

The investigations show the Glassex additive influence on bending strength and wear resistance of tested moulding sands. The results of the experiments are presented on the Figures 1-3.

The applied researches showed that Glassex additive do not decrease technological properties of moulding sands both with Ixional SD hardener and with Jefsol BC hardener. However the higher bending strength after $24 \mathrm{~h}$ hardening is observed in case of moulding sand with Jefsol BC hardener (Fig. 1-2). The Glassex additive causes lower wear resistance of moulding sand with Ixional SD. The wear resistance of moulding sand with Ixional SD is lower than the wear resistance of moulding sands with Jefsol BC. The Glassex additive 
decreases the wear resistance of moulding sand with Ixional SD. The wear resistance of moulding sands with Jefsol BC after inserting the Glassex additive is stable on high level (Fig. 3).

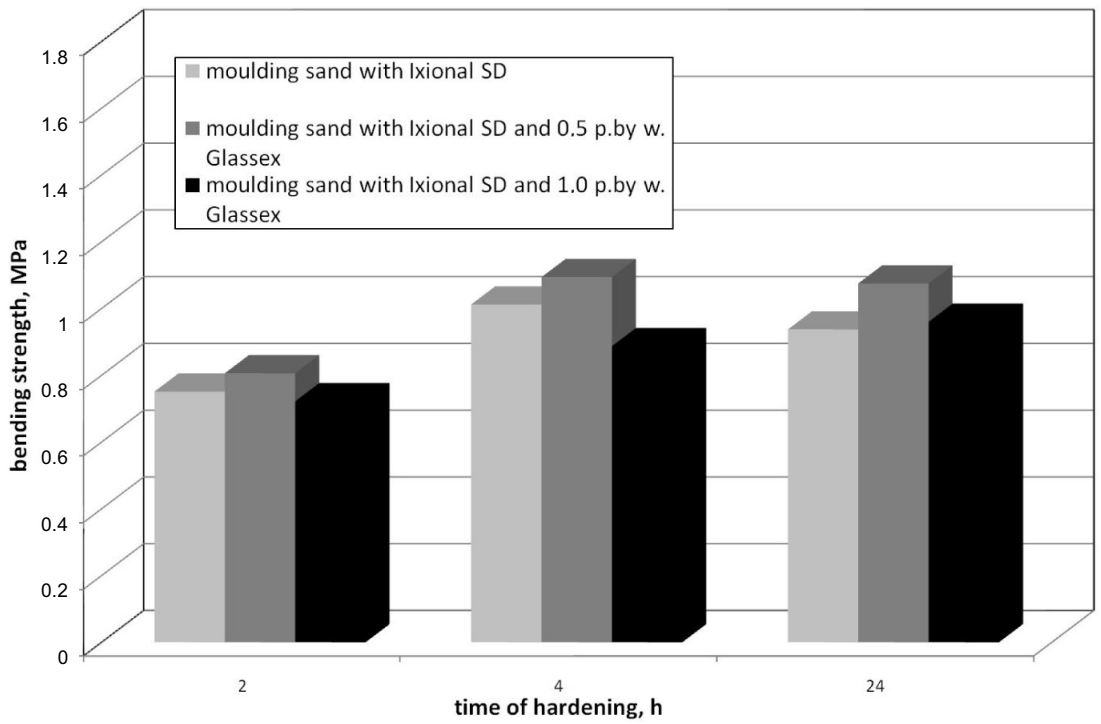

Fig. 1. The influence of Glassex additive on bending strength of moulding sand with water glass and Ixional SD hardener.

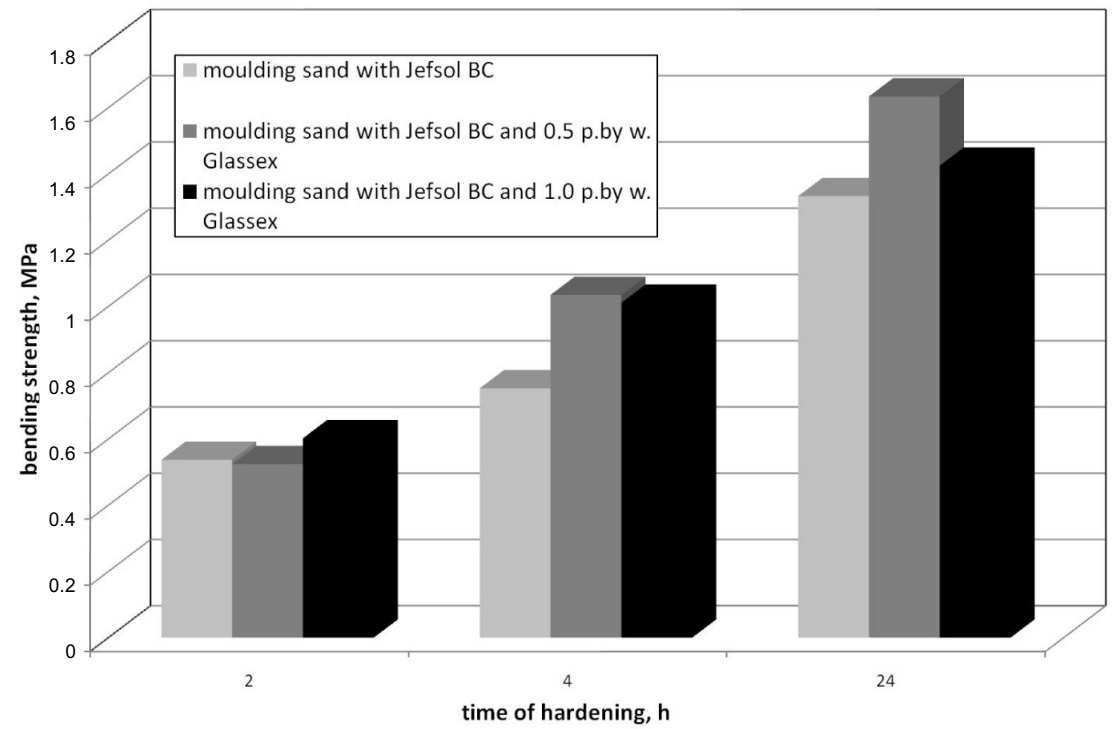

Fig. 2. The influence of Glassex additive on bending strength of moulding sand with water glass and Jefsol BC hardener 


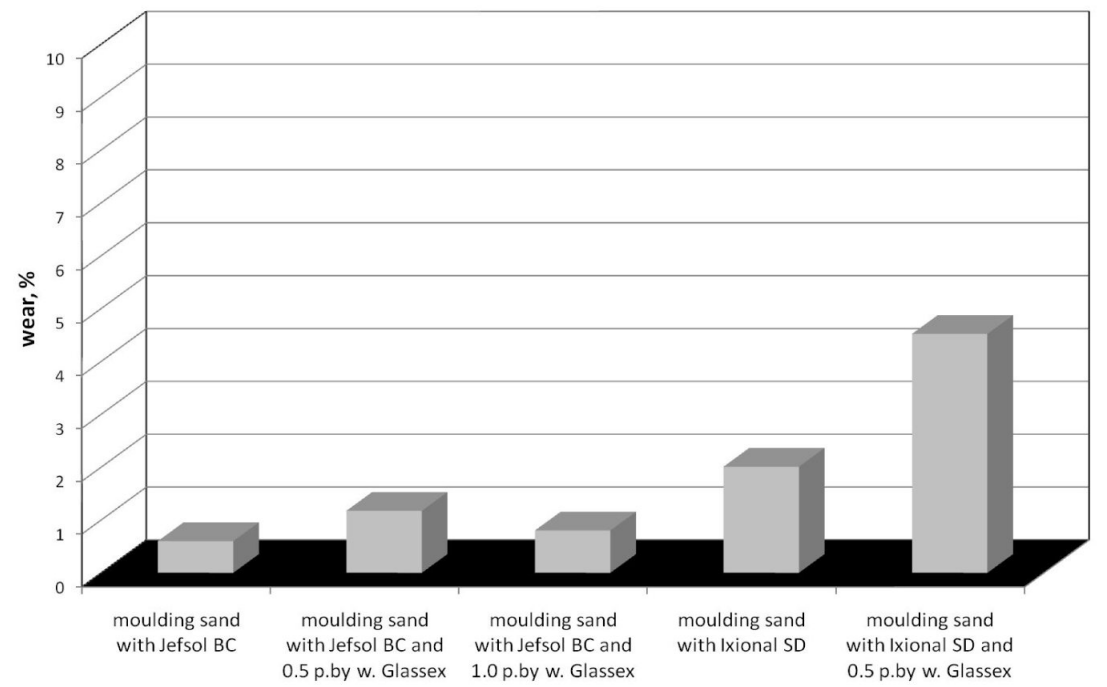

Fig. 3. The influence of Glassex additive on wear resistance moulding sand with water glass and Ixional SD and Jefsol BC hardeners

\subsection{The investigations of Glassex additive influence on knock-out properties measured by retained strength investigations of moulding sand with water glass}

The knock-out properties of the moulding sands were measured by their retained strength investigations. The results of the experiments are presented on the Figures 4-5.

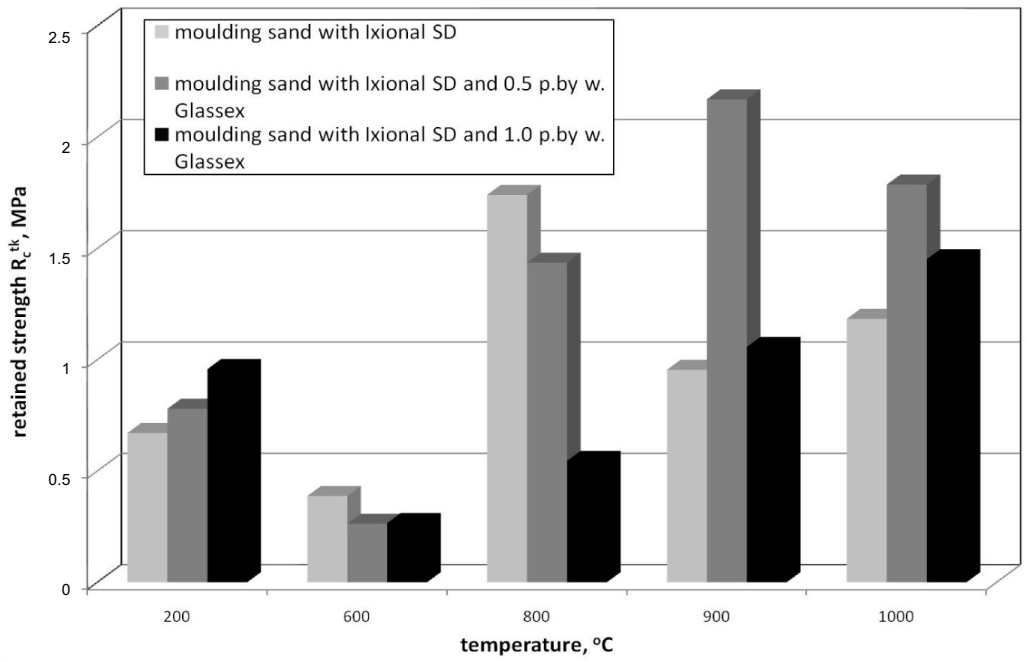

Fig. 4. The influence of Glassex additive on retained strength of moulding sand with water glass and Ixional SD hardener 


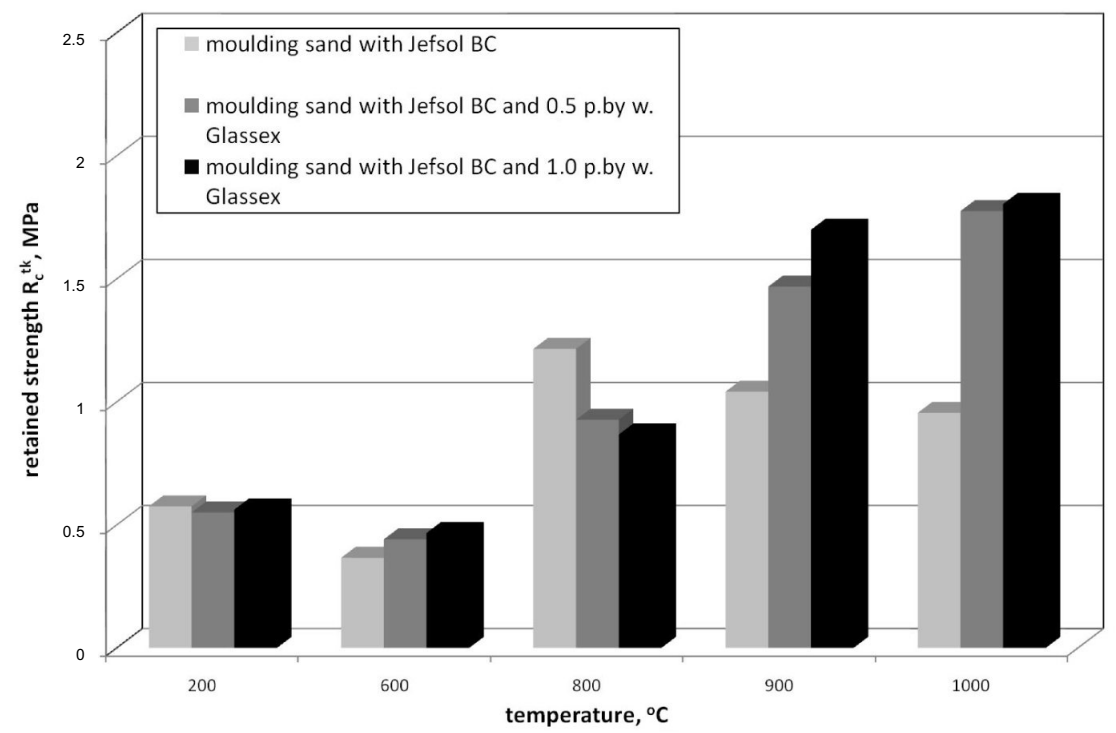

Fig. 5. The influence of Glassex additive on retained strength of moulding sand with water glass and Jefsol BC hardener

The investigations show that the Glassex additive decreases the retained strength of moulding sands with both new hardeners. The new additive also moves the second maximum into the higher temperature direction. The obtained data shows that appropriate quantity of the new additive for the moulding sands with Ixional SD is 1.0 part by weight and for the moulding sands with Jefsol BC 0.5 part by weight is enough.

The investigations also shows that - irrespective of the new Glassex additive quantity - the moulding sand with Jefsol BC hardener has lower retained strength than the moulding sand with Ixional SD.

\subsection{The investigations of Glassex additive influence on thermal expansion of moulding sand with water glass}

To confirm the obtained data the investigations of Glassex additive influence on moulding sand with water glass thermal expansion were carried out.

Thermal expansion is a parameter that describes the moulding sand ability to knocking-out in higher temperatures - the higher thermal expansion is the worse moulding sand's knock-out properties are [8]. Thermal expansion was measured by the samples volume change investigations during their heating. The final results of the experiments are presented on the Figures 6-7.

In the paper only a part of investigations of the Glassex additive influence on moulding sand's with water glass thermal expansion is placed. It is showed that the Glassex additive decreases the moulding sand thermal expansion. However the influence of the additive depends on the hardener nature (type). 


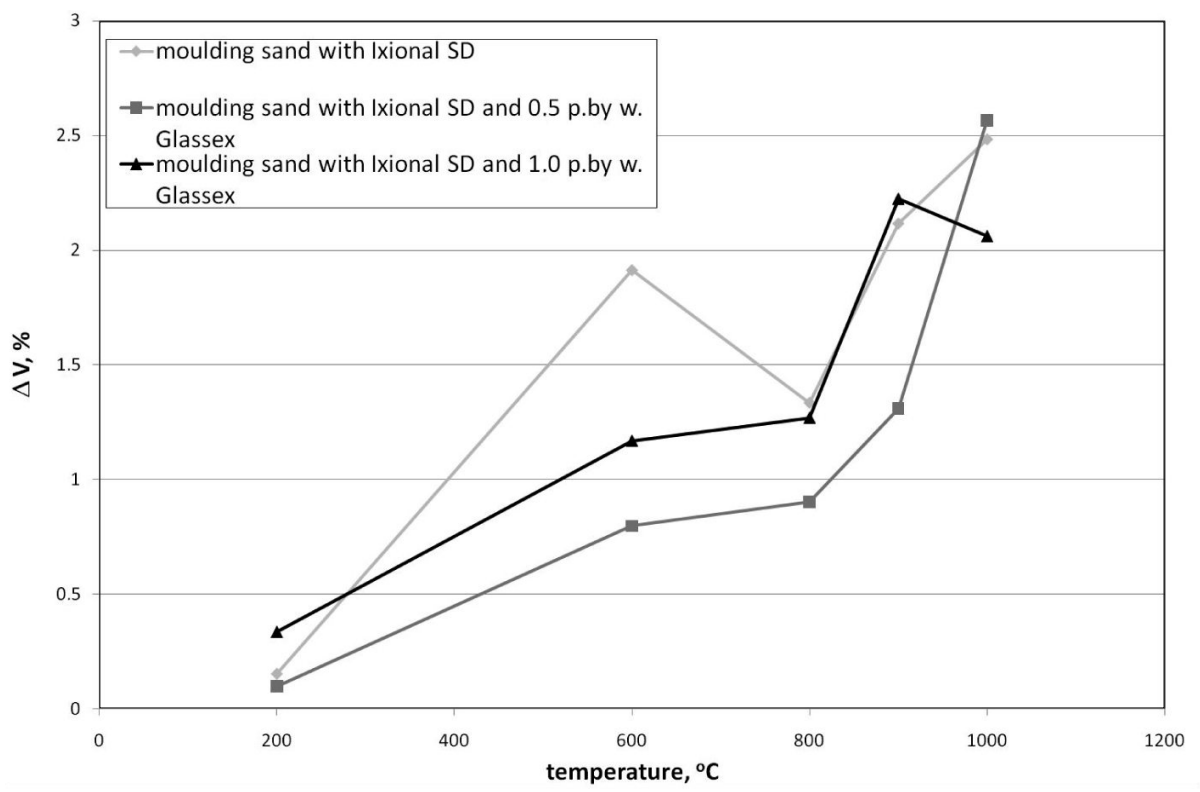

Fig. 6. The influence of Glassex additive on thermal expansion of moulding sand with water glass and Ixional SD hardener

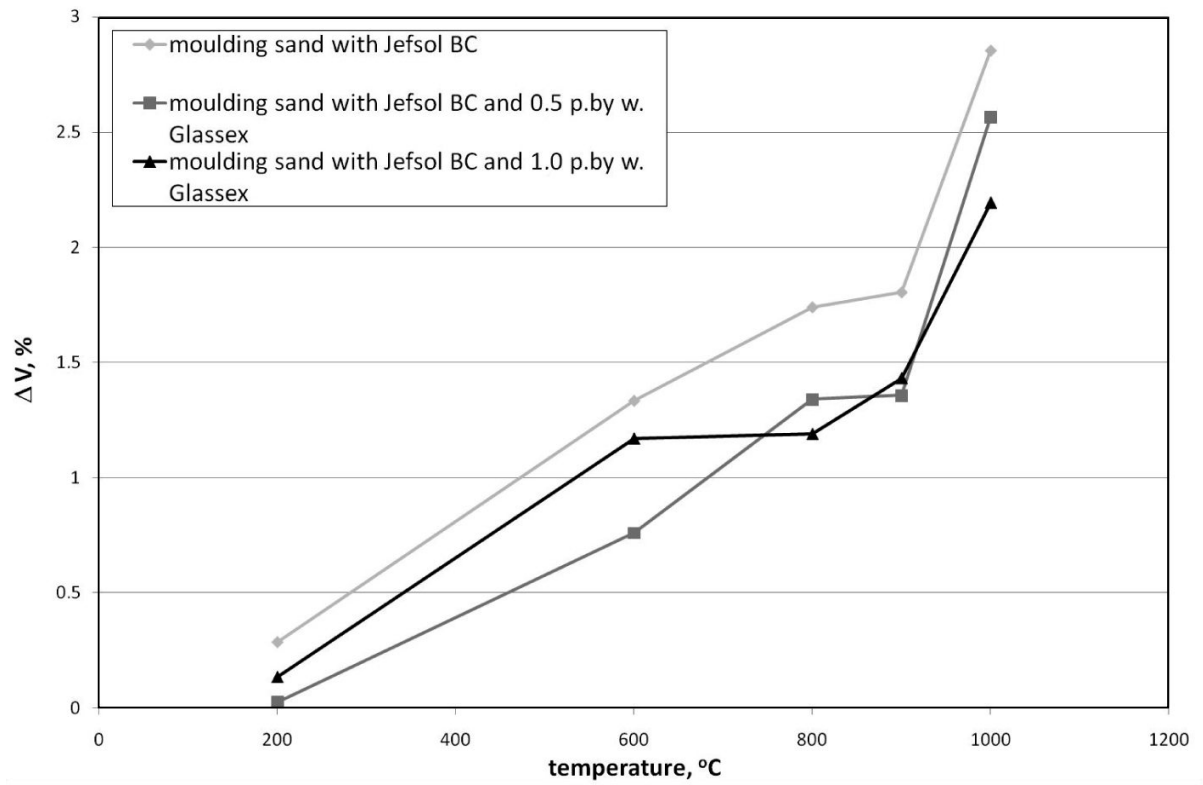

Fig. 7. The influence of Glassex additive on thermal expansion of moulding sand with water glass and Jefsol BC hardener 


\section{CONCLUSIONS}

The investigations in the paper showed that inserting the new Glassex additive to moulding sands with water glass hardened with carbonate acid esters (Ixional SD and Jefsol BC) decreases their retained strength in measured range of temperatures to the temperature of the second maximum. What's more the new additive moves the second maximum of the retained strength into the higher temperatures direction which means that the additive improves the moulding sand's knock-out properties.

The Glassex additive also decreases thermal expansion of the moulding sand with water glass. The experimental results approved the good influence of the Glassex additive on knock-out properties of moulding sands with water glass.

The Glassex additive doesn't decrease the tested moulding sands' technological properties.

The investigations showed that the moulding sand with Jefsol BC hardener has lower retained strength than the moulding sand with Ixional SD while the technological properties of the moulding sand with Jefsol $\mathrm{BC}$ are better than the technological properties of the moulding sand with Ixional SD.

Scientific research financed from AGH, No 11.11.170.318 - 3/10

\section{REFERENCES}

[1] Dobosz S.M., Major-Gabryś K.: The new additive to the mouldig sands with water glass (in Polish), DOKSEM 2003, Słowacja, Rajecke Teplice, 2003, pp. 38-41

[2] Dobosz S.M., Major-Gabryś K.: The New way of upgrading the moulding sand's with water Glass knock-out properties (In Polish), Materiały XXVII Konferencji Naukowej z Okazji Święta Odlewnika 2003, Kraków 2003, pp. 81-85

[3] Dobosz S.M., Major-Gabryś K.: Zjawiska powierzchniowe a wybijalność mas ze szkłem wodnym, Archiwum Technologii Maszyn i Automatyzacji, Komisja Budowy Maszyn PAN w Oddział w Poznaniu, 2004, pp. $49-56$

[4] Dobosz S.M., Major-Gabryś K.: Glassex - The New additive upgrading moulding sand's with water Glass knock-out properties (In Polish), Archiwum Odlewnictwa, 4 (2004) 13, 63-68

[5] Major-Gabryś K., Dobosz S.M.: Ocena wybijalności mas ze szkłem wodnym i nowym dodatkiem Glassex, Materiały XXVIII Konferencji Naukowej z Okazji Święta Odlewnika 2004, Kraków 2004, pp. 83-87

[6] Major-Gabryś K., Dobosz S.M.: The alternative ester hardeners for moulding sands with water Glass (in Polish), Mat. XXXI Konferencji Naukowej „NowoczesneTechnologie w Odlewnictwie”. AGH, 2007, pp. 33-38

[7] Dobosz S.M., Major-Gabryś K.: Moulding Sands With Water Glass With Increased Ability to Reclamation, Archives of Foundry Engineering, 8 (2008) 1, 67-70

[8] Jelinek P.: Foundry moulding sand's binding systems (in Czech), Ostrava 2004

[9] Herecova L., Jelinek P.: The carbonate acid esters - hardeners for sodium silicate binders (in Czech), Sborník vedeckých prací Vysoké školy báňské - Ostrawa, 2006, pp. 79-86

[10] Antoš P., Burian A.: The possibility of moulding sands with water glass reclamation (in Czech), Slévárenství, (2002) 5-6, 184-187 
[11] Dobosz S.M., Major-Gabryś K.: The self-herdening moulding sands with water glass and new ester harde ner (In Polish), Samoutwardzalne masy ze szkłem wodnym i nowym utwardzaczem estrowym, Inżynieria Materiałowa, 27 (2006) 3, 576-579

[12] Major-Gabryś K., Dobosz S.M.: JEFSOL BC - the new ester hardener for moulding sands with water glass having slower activity (In Polish), Mat. XXXII Konferencji Naukowej „Nowoczesne Technologie w Odlewnictwie", AGH, 2008, pp. 33-36

[13] Dobosz S.M., Major-Gabryś K.: The new aspects in using the moulding sands with water glass (in Polish), Materialove Inźinierstwo (Transactions of the Materials Engineering), (2006) 3, 14-17

[14] Major-Gabryś K., Dobosz S.M.: A new ester hardener for moulding sands with water glass having slower activity, Archives of Foundry Engineering, 9 (2009) 4, 125-128

Received

January 2011 